\title{
Polycarboxylate superplasticiser admixtures: effect on hydration, microstructure and rheological behaviour in cement pastes
}

\author{
F. Puertas*, H. Santos*, M. Palacios* and S. Martínez-Ramírez*
}

Eduardo Torroja Institute, Madrid

\begin{abstract}
A study was conducted on the effect of a polycarboxylate (PC) admixture on the mechanical, mineralogical, microstructural and rheological behaviour of Portland cement pastes. It was observed that the presence of PC admixture retards the initial cement hydration reactions, although this effect may be offset by possible increased diffusion in later stages. Additionally, the PC admixtures produce a few alterations in the structure and composition of the formed $\mathrm{C}-\mathrm{S}-\mathrm{H}$ gel. The addition of $1 \%$ PC admixture in the pastes generates a higher percentage of silicate bridge ( $\mathrm{Si} Q^{2}$ units) mainly at 2 days. The admixture used in this study induced microstructural modifications in the pastes which slightly reduced the porosity; however the admixture did not affect the mechanical strength of the pastes at either 2 or 28 days of hydration. Finally, from the results of the rheological studies it was concluded that a low dosage of PC led to a substantial reduction (over 70\%) in the yield stress.
\end{abstract}

\section{Introduction}

Substantial progress has been made in concrete technology in the last few decades, driven by the development of new types of highly improved concrete with specific characteristics and properties, including high performance concrete (strength, durability), selfcompacting concrete, etc. Organic admixtures have played a prominent role and, according to some authors, ${ }^{1}$ been even more substantial than cement in such developments.

Among the most important admixtures presently used in preparing concrete are superplasticisers, which are preferred for their ability to enhance concrete properties, making it: (a) more workable and easier to place; $(b)$ have better mechanical behaviour due to the lower water/cement ratios required; and $(c)$ cheaper because the cement content can be optimised. ${ }^{2}$

The earliest dispersive admixtures date from the 1930s; but it was not until the 1960s, with the development of sulphonated melamine formaldehydes in Ger-

* Eduardo Torroja Institute (C.S.I.C), Serrano Galvache n ${ }^{\circ} 4,28033$ Madrid, Spain.

(ACR 4480) Paper received 13 February 2004; last revised 28 October 2004; accepted 10 March 2005 many and analogous naphthalene derivatives in Japan, that superplasticiser admixtures began to be used more profusely and under more controlled conditions. ${ }^{3}$ In the late twentieth century new admixtures based on polycarboxylate ethers were developed, with structural characteristics that provided for more fluid concrete, which was more resistant to segregation and exudation than any prepared with the superplasticisers known previously. For these reasons nowadays polycarboxylate admixtures have been introduced into the cement systems replacing admixtures based on melamine and naphthalene.

The molecular structure of polycarboxylate (PC) superplasticiser admixtures is shown in Fig. $1 .^{4}$ Their 'comb-type' molecule consists of one main linear chain with lateral carboxylate and ether groups. According to the literature, ${ }^{4,5}$ the carboxylate groups are instrumental in the adsorption of these admixtures to cement particles. Dispersion is due to electrostatic repulsion (as in melamine and naphthalene admixtures) owing to the carboxylate groups, but primarily to the steric repulsion associated with the long lateral ether chains. The high degree and duration of the fluidity that this admixture affords concrete are related to structural factors; hence, the shorter the main chain and the longer and more numerous the lateral chains, the greater and more longlasting is the fluidity induced. ${ }^{6}$ The molecular weight 


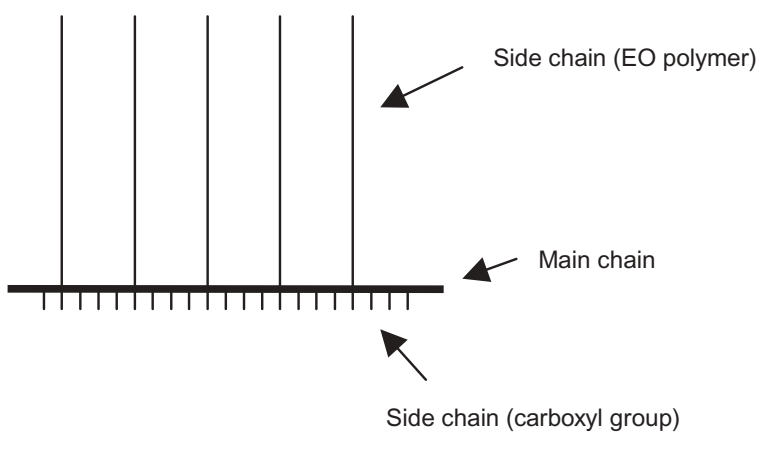

Fig. 1. Chemical structure of polycarboxylate admixture $e^{4,6}$

of these admixtures likewise has a substantial effect on their performance: according to R. Magarotto et al., ${ }^{7}$ adsorption and system fluidity are proportionally higher in polymers with large molecular weight.

The use of PC admixtures makes it possible to reduce the water content by up to $40 \%$, producing workable, high performance and therefore very resistant concrete. ${ }^{8}$ Owing to these characteristics, the development and use of such superplasticisers has been related to the preparation and formulation of self-compacting concrete.

Nonetheless, the use of admixtures may have drawbacks associated with variations in fluidity, setting, etc., often related to cement-admixture compatibility. In their interaction with cement components, superplasticisers retard hydration ${ }^{9}$ and affect product morphology and microstructure. ${ }^{10}$ Generally speaking, the effect of superplasticisers on cement hydration is assumed to involve several factors. ${ }^{11}$

The molecules of the superplasticiser hinder water and $\mathrm{Ca}^{2+}$ ion diffusion across the solution-cement interface.

The $\mathrm{Ca}^{2+}$ ions form complexes with the superplasticiser molecules, inhibiting the nucleation and growth of Ca-rich species.

The strong dispersive action of these admixtures alters reaction product formation kinetics and morphology.

Many researchers have explored the changes taking place in clinker and cement characteristics when fluidity is induced by melamine (SMF) and naphthalene (SNF) superplasticisers. The chief findings of these studies are summarised in references 12 and 13. The initial dispersive effect is directly related to adsorption, which is in turn affected by the following factors: $\mathrm{C}_{3} \mathrm{~A}$ and alkali content in the clinker, cement fineness, type of calcium sulphate used and content of this compound used to regulate setting, dosage and method used to add the superplasticiser, molecular weight and degree of sulphonation of the admixture, and so on. However,

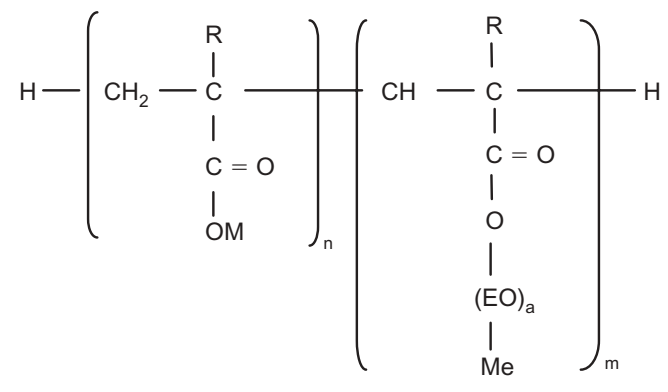

$$
\begin{aligned}
& M=\text { metal } \\
& M e=\text { methyl } \\
& E O=\text { oxyethylene } \\
& R=M e, H
\end{aligned}
$$

the effect of polycarboxylate (PC) admixtures on cement hydration has received less attention and is therefore less well understood. Recently, Moulin and Broker ${ }^{14}$ showed that PC admixture-induced fluidity depends on the type of calcium sulphate utilised, a dependence that is attenuated in the presence of a moderate $\mathrm{C}_{3} \mathrm{~A}$ content.

Superplasticiser admixtures are chiefly used for the improvements they make in the rheological properties of fresh concrete. Nonetheless, the relationship between cement paste and fresh concrete rheology has yet to be established, since under real conditions the other components (i.e., aggregate) of concrete also affect its rheology. ${ }^{15}$ In any event, it is important to know how superplasticiser admixtures affect the rheological properties of cement paste, since this will provide information on: ${ }^{12}$

(a) the evolution of hydrated products

(b) the relative behaviour of different superplasticiser admixtures

(c) cement-admixture compatibility.

The basic objective of the present research is the systematic study of the effect of a polycarboxylate admixture on hydration and microstructure of Portland cement pastes. Rheological studies and their relationship with hydration processes are likewise shown.

\section{Experimental}

\section{Materials}

Table 1 shows the chemical and mineralogical analysis of the Portland cement used in this study [CEM I 42.5 R (EN 197-1:2000)]. X-ray diffraction (XRD) and infrared spectroscopic (FTIR) mineralogical characterisation of this cement show the principal constituent to be alite, along with belite, $\mathrm{C}_{3} \mathrm{~A}$ and ferrite. Sulphate is present in the form of gypsum. 
Table 1. Chemical and mineralogical composition of Portland cement (\% by mass)

\begin{tabular}{l|c|c|c|c|c|c|c|c|c}
\hline LOI.* & $\begin{array}{c}\text { Insoluble } \\
\text { residue }\end{array}$ & $\mathrm{SiO}_{2}$ & $\mathrm{Al}_{2} \mathrm{O}_{3}$ & $\mathrm{Fe}_{2} \mathrm{O}_{3}$ & $\mathrm{CaO}$ & $\mathrm{MgO}$ & $\mathrm{SO}_{3}$ & $\mathrm{Na}_{2} \mathrm{O}$ & $\mathrm{K}_{2} \mathrm{O}$ \\
\hline 0.79 & 0.17 & 18.95 & 5.89 & 4.50 & 63.83 & 2.21 & 2.85 & 0.29 & 0.75 \\
\hline
\end{tabular}

$\mathrm{C}_{3} \mathrm{~S}=61 \cdot 6 \% ; \mathrm{C}_{2} \mathrm{~S}=8 \% ; \mathrm{C}_{3} \mathrm{~A}=8 \% ; \mathrm{C}_{4} \mathrm{AF}=13 \cdot 7 \%$

Blaine: $403 \cdot 7 \mathrm{~m}^{2} / \mathrm{kg}$.

* Loss of ignition.

Table 2 shows some of the physical and chemical characteristics of the polycarboxylate admixture used in this study. FTIR, ${ }^{1}$ proton-nuclear magnetic resonance (H-NMR) and ultra-violet and visible (UV-V) structural analyses indicate that the admixture comprises molecular chains consisting primarily of esters, carboxylate salts and ether groups. The high rotational viscosity found indicates that the respective polymer contains very long and abundantly branched chains. ${ }^{16,17}$

\section{Tests conducted}

Cement pastes with a w/c ratio of 0.4 were prepared. From 0 to $1 \%$ of superplasticiser was added to the batch water in all the tests. The pastes obtained were cured in chambers kept at a relative humidity of $99 \%$ and $21 \pm 2{ }^{\circ} \mathrm{C}$. The following tests were run.

Mechanical strengths. Prismatic specimens measuring $1 \mathrm{~cm} \times 1 \mathrm{~cm} \times 6 \mathrm{~cm}$ were prepared and tested for flexural and compression strength after 2 and 28 days.

Hydration studies. The following tests were conducted.

(a) Conduction calorimetry. The test was run on a Wexham Developments JAF model isothermal calorimeter, using IBM program AWCAL-4, at a temperature of $22^{\circ} \mathrm{C}$ for a maximum of 70 hours. Fifteen grams of cement was mixed with water and admixture before introducing it into the calorimeter cell.

(b) Thermogravimetric analysis (TGA). A Netzsch model STA 409 simultaneous thermal analyser equipped with a Data Acquisition System 414/1 programmer was used for the tests. Samples were heated from 100 to $1050^{\circ} \mathrm{C}$, at a heating rate of $4^{\circ} \mathrm{C} /$ min in an inert $\mathrm{N}_{2}$ atmosphere.

Table 2. Physical and chemical characteristics of the polycarboxylate admixture

\begin{tabular}{l|c}
\hline Appearance & Yellow-brown liquid \\
$\%$ solid residue & Approx. $38 \%$ \\
$\mathrm{pH}$ & $5 \cdot 3-5 \cdot 4$ \\
Specific gravity : $\mathrm{kg} / 1$ & Approx. $1 \cdot 09$ \\
Rotational viscosity: $\mathrm{MPa}$ & $79 \cdot 50$ \\
$\% \mathrm{C}$ & $52 \cdot 49$ \\
$\mathrm{ppm} \mathrm{Na}$ & 9200 \\
$\mathrm{ppm} \mathrm{K} \mathrm{K}^{+}$ & 162 \\
\hline
\end{tabular}

Advances in Cement Research, 2005, 17, No. 2 (c) Setting times, as prescribed in Spanish standard UNE-EN 196-3.

Mineralogical and microstructural studies. Pastes were characterised after 2 and 28 days of hydration. The following tests were run.

(a) X-ray diffraction (XRD). A Philips PW-1730 unit was used; records were taken at $2 \theta$ intervals, from 5 to $60^{\circ}$.

(b) FT-infrared spectroscopy (FTIR). An Atimattson spectroscope was used. The $\mathrm{KBr}$ pellet methodology was used to prepare the solid samples, which were covered at frequencies ranging from 4000 to $400 \mathrm{~cm}^{-1}$.

(c) FT-Raman spectroscopy. FT-Raman spectra (RFS 100/S Bruker spectrophotometer) were obtained using as the excitation source a $\mathrm{Nd}$ :YAG laser at $1064 \mathrm{~nm}$. The resolution was set to $4 \mathrm{~cm}^{-1}$ and $180^{\circ}$ geometry was employed. The samples were treated with a laser power of $100 \mathrm{~mW}$. In order to improve the signal-to-noise ratio, 1000 scans, corresponding to a measurement time of $30 \mathrm{~min}$, were typically coadded.

(d) Solid nuclear magnetic resonance (NMR MAS). The positions occupied by ${ }^{29} \mathrm{Si}$ and ${ }^{27} \mathrm{Al}$ atoms can be determined with this technique. A Bruker MSL 400 machine was used. Tetramethyl-silane (TMS) was taken as a reference pattern for the ${ }^{29} \mathrm{Si}$ spectra, whereas the ${ }^{27} \mathrm{Al}$ spectra reference was an aluminium trichloride solution.

(e) Mercury intrusion porosimetry. A Micromeritics 9320 pore size was used.

(f) Scanning electron microscopy (SEM) and X-ray dispersive energy analysis (EDX). These tests were run on a Joel 5400 unit with an Oxford-Link ISIS System EDX spectrophotometer. Backscattering electron (BSE) imaging was used to study the samples, which were prepared under conditions that ensured their subsequent viability for analytical purposes.

Rheological behaviour. Rheological parameters were determined (plastic viscosity and yield stress) with a rate-controlled coaxial cylinder viscosimeter [Haake Rheowin pro RV1 using a Z38 rotor with serrated surface $\left.\left(R_{\mathrm{i}}=19.010 \mathrm{~mm} ; h=55 \mathrm{~mm}\right)\right]$. One 
hundred gram cement samples were mixed with water and admixture with a vane stirrer (RW-20 JankeKunder) for $3 \mathrm{~min}$. The liquid/cement ratio was kept fixed at 0.4 values. Measurements were taken at shear rates ranging from 5 to $27 \mathrm{~s}^{-1}$.

\section{Results}

\section{Mechanical strength}

The strength values found for the pastes prepared, after 2 and 28 days, are given in Table 3. This table shows that at a constant water/cement ratio $(\mathrm{w} / \mathrm{c}=0.4)$, the addition of the PC superplasticiser, at the dosage used, does not induce any substantial modifications in paste strength values.

\section{Hydration studies}

Conduction calorimetry. The heat release rate curve charts for the different pastes studied are given in Fig. 2. Two signals can be distinguished on all these charts: a peak corresponding to the acceleration or post-induction period, associated with the precipitation of $\mathrm{C}-\mathrm{S}-\mathrm{H}$ gel and $\mathrm{CH}$, and a shoulder related to a second, weaker signal with a later peak time, associated with the transformation from the ettringite (AFt) to the calcium monosulphoaluminate (AFm) phase via dissolution and reaction with $\mathrm{Al}(\mathrm{OH})_{4}{ }^{-18}$ The numerical

\section{Table 3. Mechanical strengths}

\begin{tabular}{l|c|c|c|c}
\hline $\begin{array}{l}\text { Dosage } \\
\text { admixture: }\end{array} \%$ & \multicolumn{2}{|c|}{2 days } & \multicolumn{2}{c}{28 days } \\
\cline { 2 - 5 }$\%$ & $\begin{array}{c}\text { Flexion: } \\
\mathrm{MPa}\end{array}$ & $\begin{array}{c}\text { Compression: } \\
\mathrm{MPa}\end{array}$ & $\begin{array}{c}\text { Flexion: } \\
\mathrm{MPa}\end{array}$ & $\begin{array}{c}\text { Compression: } \\
\mathrm{MPa}\end{array}$ \\
\hline 0 & $3 \cdot 3$ & $52 \cdot 7$ & $6 \cdot 3$ & $62 \cdot 7$ \\
$0 \cdot 3$ & $3 \cdot 9$ & $48 \cdot 3$ & $9 \cdot 2$ & $55 \cdot 1$ \\
$0 \cdot 5$ & $3 \cdot 3$ & $49 \cdot 5$ & $6 \cdot 4$ & $62 \cdot 4$ \\
$0 \cdot 7$ & $3 \cdot 6$ & $54 \cdot 3$ & $7 \cdot 2$ & $61 \cdot 6$ \\
1 & $3 \cdot 0$ & $53 \cdot 6$ & $5 \cdot 4$ & $65 \cdot 1$ \\
\hline
\end{tabular}

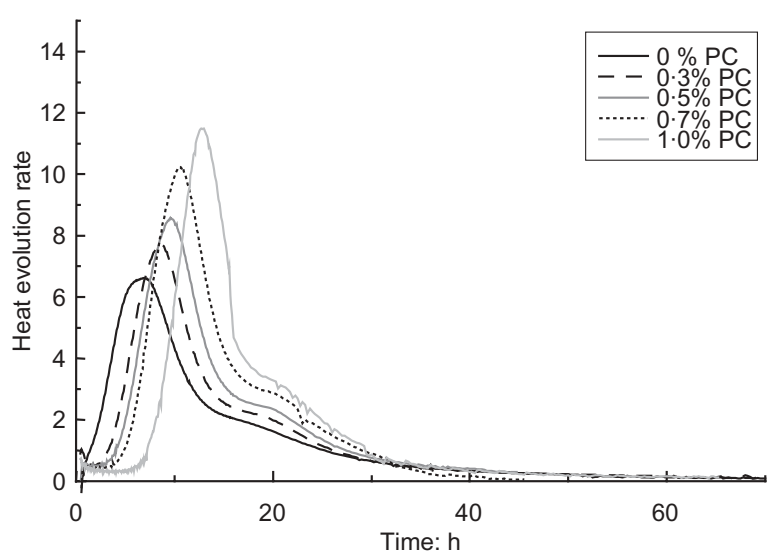

Fig. 2. Heat evolution rate curve for cement pastes values corresponding to these two signals (heat release rate, peak times) and the total heat released are shown in Table 4. The time period over the total heat was measured until the heat release rate was below $1 \%$ of the maximum of the second peak.

The heat release rate curves in Fig. 2 and values in Table 4 show that increasing the percentage of admixture in the pastes retards peak times and raises heat release rate values. This is indicative of a delay in initial cement hydration due to the presence of the admixture. The retardation is much less marked in the second peak. The total heat released under identical conditions (at times when the heat release rate is less than $1 \%$ of the maximum amount of heat released in the first peak) increases with higher percentages of PC superplasticisers in the mix.

Thermogravimetric analysis. Table 5 shows the weight loss measured in two temperature ranges, namely $110-600^{\circ} \mathrm{C}$ and $600-1050^{\circ} \mathrm{C}$. It will be noted from this table that pastes containing the admixture and cured for 2 days in the $110-600^{\circ} \mathrm{C}$ range (associated with dehydration of hydrated products), lose less weight than pastes cured under the same conditions but without the superplasticiser. The loss is 6 to $11 \%$ smaller, depending on admixture content. After 28 days, however, this effect is much less acute, with a lower decrease (less than 5\%) in loss in this same temperature range. These results confirm that the initial hydration reactions are retarded by the $\mathrm{PC}$ admixture.

The losses between 600 and $1050^{\circ} \mathrm{C}$ are essentially associated with the decomposition of the carbonates formed, primarily by weathering. The effect of the admixtures in this thermal range is hardly significant

Table 4. Calorimetric results of cement pastes

\begin{tabular}{l|c|c|c|c|c}
\hline $\begin{array}{l}\text { Dosage } \\
\text { admixture: } \\
\%\end{array}$ & Total heat: & \multicolumn{2}{|c|}{ First peak } & \multicolumn{2}{c}{ Second peak } \\
\cline { 2 - 6 } & $\mathrm{kJ} / \mathrm{kg}$ & $\begin{array}{c}\text { Time: } \\
\mathrm{h}\end{array}$ & $\begin{array}{c}\text { Rate: } \\
\mathrm{W} / \mathrm{kg}\end{array}$ & $\begin{array}{c}\text { Time: } \\
\mathrm{h}\end{array}$ & $\begin{array}{c}\text { Rate: } \\
\mathrm{W} / \mathrm{kg}\end{array}$ \\
\hline 0 & $296 \cdot 4$ & $1 \cdot 2$ & $0 \cdot 54$ & $14 \cdot 6$ & $2 \cdot 32$ \\
$0 \cdot 3$ & $311 \cdot 1$ & $2 \cdot 7$ & $0 \cdot 68$ & $14 \cdot 7$ & $2 \cdot 62$ \\
$0 \cdot 5$ & $339 \cdot 1$ & $4 \cdot 0$ & $0 \cdot 88$ & $15 \cdot 1$ & $3 \cdot 06$ \\
$0 \cdot 7$ & $376 \cdot 2$ & $5 \cdot 1$ & $1 \cdot 15$ & $16 \cdot 0$ & $3 \cdot 66$ \\
1 & $408 \cdot 2$ & $7 \cdot 7$ & $1 \cdot 31$ & $19 \cdot 0$ & $3 \cdot 91$ \\
\hline
\end{tabular}

Table 5. Weight loss (\%) of the pastes in the ranges 110 $600^{\circ} \mathrm{C}$ and $600-1050^{\circ} \mathrm{C}$

\begin{tabular}{l|c|c|c|c}
\hline \multirow{2}{*}{$\begin{array}{l}\text { Dosage } \\
\text { admixture: }\end{array}$} & \multicolumn{2}{|c|}{2 days } & \multicolumn{2}{c}{28 days } \\
\cline { 2 - 5 }$\%$ & $110-600^{\circ} \mathrm{C}$ & $600-1050^{\circ} \mathrm{C}$ & $110-600^{\circ} \mathrm{C}$ & $600-1050^{\circ} \mathrm{C}$ \\
\hline 0 & 8.26 & 3.51 & $10 \cdot 15$ & 4.46 \\
0.3 & 7.70 & 2.94 & $10 \cdot 50$ & 4.33 \\
0.5 & 7.69 & 3.11 & 9.76 & 4.01 \\
0.7 & 7.31 & 3.74 & $10 \cdot 10$ & 3.67 \\
1 & 7.30 & 2.98 & 9.65 & 3.63 \\
\hline
\end{tabular}

Advances in Cement Research, 2005, 17, No. 2 
after 2 days of hydration; after 28 days, however, a progressive decline in weight loss is recorded as superplasticiser content rises.

Setting times. The setting times of the pastes studied are given in Table 6, which shows that as the percentage of the PC admixture increases, setting times lengthen. These data concur with the results of conduction calorimetry and, to some extent, with the thermogravimetric findings; that is, these superplasticisers retard initial cement hydration, an effect that is intensified as the admixture content increases.

\section{Mineralogical and microstructural studies}

The mineralogical and microstructural analyses were carried out on frozen cement paste with acetone and alcohol, after 2 and 28 days of hydration.

$X$-ray diffraction (XRD). The analysis of the respective diffractograms shows no substantial differences in paste mineralogical composition at the ages studied ( 2 and 28 days). The same crystalline phases can be identified in all the samples: alite, belite, $\mathrm{C}_{3} \mathrm{~A}$, $\mathrm{C}_{4} \mathrm{AF}, \mathrm{AFt}$ (ettringite) and $\mathrm{CH}$. It may be deduced from the above results that the presence of the $\mathrm{PC}$ admixture induces no mineralogical modifications in the pastes at the ages studied ( 2 and 28 days).

Fourier transform infrared spectroscopy (FTIR). IR spectra of the pastes studied after 2 and 28 days are given in Fig. 3. The analysis of these IR spectra of the hydrated paste after 2 days confirms the formation, in all the pastes, of hydrated calcium silicate $(\mathrm{C}-\mathrm{S}-\mathrm{H}$ gel), given the shift of the $v_{3}$ band $(\mathrm{Si}-\mathrm{O})$ corresponding to the $\mathrm{SiO}_{4}$ tetrahedrons from $922 \mathrm{~cm}^{-1}$ in anhydrous cement to $969-967 \mathrm{~cm}^{-1}$ in the hydrated pastes. Shift is likewise observed in the $v_{4}\left(\mathrm{SiO}_{4}\right)$ band, from $522 \mathrm{~cm}^{-1}$ in the anhydrous cement to lower frequencies $\left(454 \mathrm{~cm}^{-1}\right)$, characteristic of alite hydration and the formation of the $\mathrm{C}-\mathrm{S}-\mathrm{H}$ gel. These shifts are essentially identical in all the pastes and are not influenced by the admixture content in the mix.

Absorption values characteristic of portlandite $(\mathrm{O}-\mathrm{H}$ stretching vibrations at $3646 \mathrm{~cm}^{-1}$ ), sulphates (gypsum in anhydrous cement, $v_{3}\left(\mathrm{SO}_{4}\right)$, at 1120 and 1144 $\mathrm{cm}^{-1},{ }^{19}$ and ettringite in hydrated pastes with $v_{3}\left(\mathrm{SO}_{4}\right)$ at $\left.1115 \mathrm{~cm}^{-1}\right),{ }^{20}$ aluminates $\left[\mathrm{C}_{3} \mathrm{~A}\right.$, in the anhydrous cement as the band at $742 \mathrm{~cm}^{-1}$ assigned to $\left.v_{1}\left(\mathrm{AlO}_{4}\right)^{21}\right]$, and calcium carbonate $\left[v_{3}\left(\mathrm{CO}_{3}\right)\right.$ at $1420-$ $1480 \mathrm{~cm}^{-1}, v_{2}\left(\mathrm{CO}_{3}\right)$ at $840-860 \mathrm{~cm}^{-1}$ and $v_{1}\left(\mathrm{CO}_{3}\right)$ at
$712 \mathrm{~cm}^{-1}$ ] can likewise be identified on these IR spectra. The presence of the admixture induces no significant differences in the mineralogical composition of the paste at this age.

In the IR spectra for the 28-day pastes (see Fig. 3) the $v_{3}(\mathrm{Si}-\mathrm{O})$ band appears at $988 \mathrm{~cm}^{-1}$ in the sample with no admixture, whereas in the pastes with the admixture the band is observed at lower frequencies, namely $977-974 \mathrm{~cm}^{-1}$. The position of this band is associated with the degree of condensation of the tetrahedral silicate chains and the $\mathrm{Ca} / \mathrm{Si}$ of the $\mathrm{C}-\mathrm{S}-\mathrm{H}$ gel. ${ }^{22}$ The lower the shift of this band towards higher frequencies, the greater is the condensation and lower the $\mathrm{Ca} / \mathrm{Si}$ ratio in the gel. These results indicate that the presence of the $\mathrm{PC}$ superplasticiser in the mixes induces the formation of a less condensed $\mathrm{C}-\mathrm{S}-\mathrm{H}$ gel with a higher $\mathrm{Ca} / \mathrm{Si}$ ratio.

FT-Raman spectroscopy. FT-Raman spectra of the anhydrous cement as well as the cement hydrated with both water and PC superplasticiser for 2 and 28 days were recorded in the $100-3500 \mathrm{~cm}^{-1}$ range (Fig. 4). The main differences between the different spectra are observed in the $700-1000 \mathrm{~cm}^{-1}$ region. After 2 days of hydration, the spectrum presents a band centred at $654 \mathrm{~cm}^{-1}$ with a shoulder at $740 \mathrm{~cm}^{-1}$ as well as a small peak at $811 \mathrm{~cm}^{-1}$. After 28 days of hydration, the area of the peak at $811 \mathrm{~cm}^{-1}$ increases slightly, whereas the other ones remain unchanged.

Kirkpatrick et al. ${ }^{23}$ attributed the bands in the 800$1060 \mathrm{~cm}^{-1}$ range to $\mathrm{Si}-\mathrm{O}$ stretching vibrations in $\mathrm{Q}^{1}$, $\mathrm{Q}^{2}$, and $\mathrm{Q}^{3} \mathrm{SiO}_{4}$ tetrahedral units. Moreover, the bands in the $600-700 \mathrm{~cm}^{-1}$ range are assigned to symmetrical $\mathrm{Si}-\mathrm{O}-\mathrm{Si}$ bending vibrations in $\mathrm{Q}^{1}, \mathrm{Q}^{2}$, and $\mathrm{Q}^{3}$ units. From Dyer ${ }^{24}$ the anomalously high intensity of the band at $654 \mathrm{~cm}^{-1}$ could be due to fluorescence; in this case we think that fluorescence is also possible and for this reason no main differences have been observed in the FT-Raman spectra of the samples with and without admixture.

Solid nuclear magnetic resonance (NMR). Fig. 5 shows ${ }^{29} \mathrm{Si}$ and ${ }^{27} \mathrm{Al}$ spectra of different cement pastes. Tables 7 and 8 present the data obtained by deconvolution of these spectra. The ${ }^{29} \mathrm{Si}$ MAS NMR spectrum of anhydrous cement presents a peak at $-72 \mathrm{ppm}$ assigned to $\mathrm{SiO}_{4}$ tetrahedral of calcium silicates of clinker $\left(\mathrm{C}_{3} \mathrm{~S}\right.$ and $\left.\mathrm{C}_{2} \mathrm{~S}\right){ }^{25}$ The spectra of hydrated pastes have three peaks, one from the anhydrous silicates at $-72 \mathrm{ppm}$, and others at

Table 6. Setting times of the cement pastes

\begin{tabular}{l|l|l|l|l|l}
\hline Setting times & $0 \%$ & $0 \cdot 3 \%$ & $0 \cdot 5 \%$ & $0 \cdot 7 \%$ & $1 \%$ \\
\hline Initial & $3 \mathrm{~h} 16 \mathrm{~min}$ & $6 \mathrm{~h} 32 \mathrm{~min}$ & $7 \mathrm{~h} 43 \mathrm{~min}$ & $11 \mathrm{~h} 12 \mathrm{~min}$ & $12 \mathrm{~h} 07 \mathrm{~min}$ \\
Final & $5 \mathrm{~h} 26 \mathrm{~min}$ & $9 \mathrm{~h} 17 \mathrm{~min}$ & $16 \mathrm{~h} 42 \mathrm{~min}$ & $23 \mathrm{~h} 26 \mathrm{~min}$ & n.d. \\
\hline
\end{tabular}

n.d., not determined 

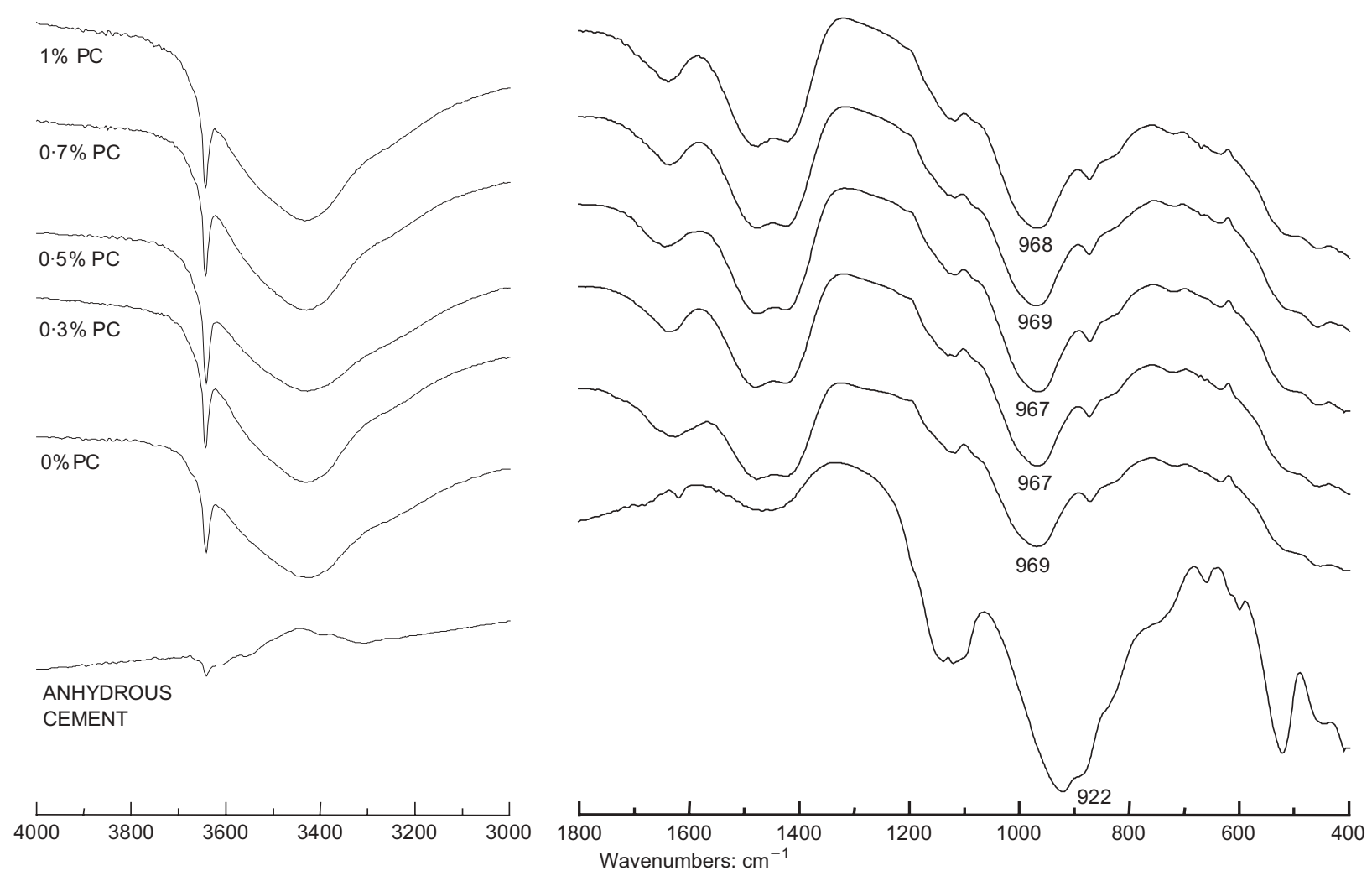

(a)
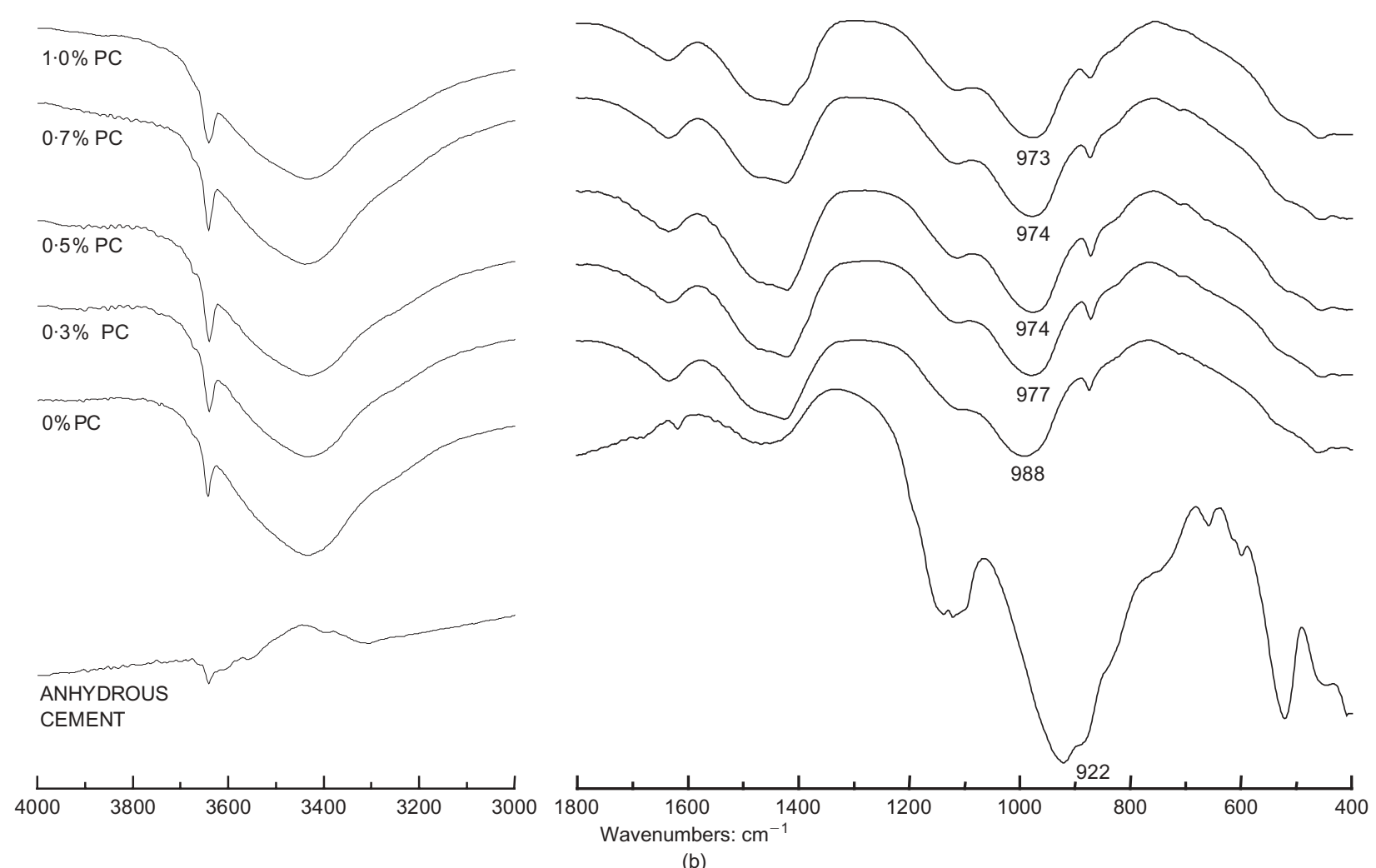

(b)

Fig. 3. Infrared spectra of cement pastes: (a) 2 days, (b) 28 days of curing 


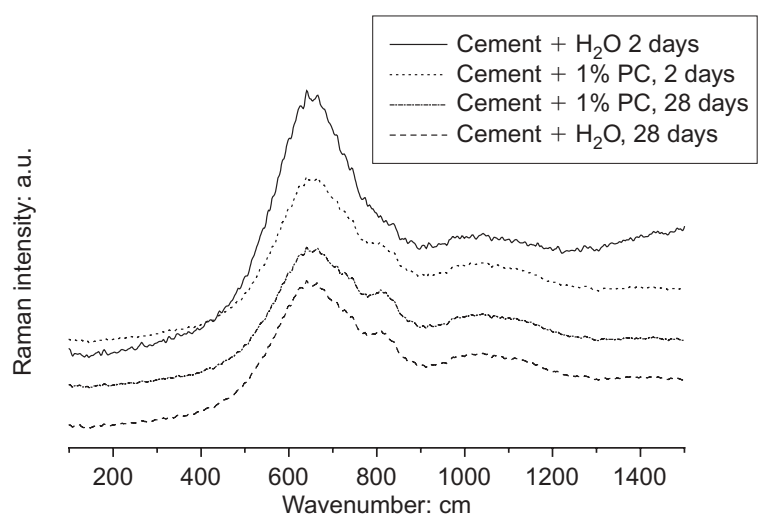

Fig. 4. FT-Raman spectra of cement pastes with $1 \%$ of PC at 2 and 28 days of curing

- $79 \mathrm{ppm}$ (assigned to $\mathrm{Q}^{1}$ units from end $\mathrm{SiO}_{4}$ tetrahedral groups) and $-85 \mathrm{ppm}$ (assigned to $\mathrm{Q}^{2}$ units due to bridging $\mathrm{SiO}_{4}$ groups). From the analysis of the data obtained (see Table 7) it is deduced in pastes with admixture, at 2 and 28 days of reaction, the $\mathrm{C}-\mathrm{S}-\mathrm{H}$ gel formed has a slightly higher $\mathrm{Q}^{2} / \mathrm{Q}^{1}$ ratio, and a slight increase of reaction degree in cement pastes with admixture is observed at 28 days.

The ${ }^{27} \mathrm{Al}$ MAS NMR spectra of anhydrous cement paste presents two signals at 80 and $62 \mathrm{ppm}$ that were assigned to tetrahedral co-ordinated $\mathrm{Al}$ in $\mathrm{C}_{3} \mathrm{~A}$ and also by solid solution in alite. ${ }^{25}$ Other small peaks were detected at 35 and $6 \mathrm{ppm}$ and assigned at pentahedral and octahedral co-ordinated Al, respectively. The spectra of hydrated pastes show a shift of the maximum signal from 80 to $70 \mathrm{ppm}$, as well as the conversion of the tetrahedral Al to octahedral co-ordination. In these areas several peaks were observed: at $13 \mathrm{ppm}$ indicative of the presence of ettringite, ${ }^{26}$ and at 8.5, 4.5 and $1.0 \mathrm{ppm}$, which were assigned to different aluminate hydrate phases. The amount of hydrate phases increases with the reaction time and the presence of admixture does not induce changes in the content of the different hydrates.

Mercury intrusion porosimetry. The results obtained with this technique are given in Tables 9 and 10. It may be deduced from Table 9 that the effect of PC dosage on paste porosity is apparent after 2 days of hydration, with a decrease in total porosity and mean pore diameter as the admixture content rises. This effect is not as clearly visible in the pastes cured for 28 days.

Mercury intrusion porosimetry can be used only to determine the percentage of air pores and of macroand mesopores in materials. The numerical data in Table 10 show that after 2 days, as the PC admixture content in the cement paste is increased, the percentage of macropores decreases and the fraction of mesopores rises, particularly in mixes with 0.7 and $1.0 \%$ of superplasticiser. This, naturally, concurs with the data given in Table 9, relative to the mean diameter of pores in pastes with higher percentages of admixture. The pore structure of pastes of this age would appear to be refined by the presence of the admixture. Nonetheless, after 28 days no substantial variation was observed in the distribution of pore size in pastes with and without admixtures.

Scanning electron microscopy. This microstructural study was performed on pastes with no admixture at all and those containing the maximum dosage, or $1 \%$, after 2 and 28 days of curing. The BSE morphological analysis evinced no substantial differences in either the form or the texture of the different reaction products in pastes with and without admixtures. The morphologies of the pastes studied can be seen in the micrographs in Fig. 6.

The micrographs corresponding to paste cured for 2 days show anhydrous cement that has not yet reacted, along with a relatively porous mass corresponding to the reaction products. This region is more compact and less porous in the paste with admixture. After 28 days, the reaction is observed to progress, with a significant decrease in the amount of anhydrous cement particles. The atomic ratios found in an analysis performed on the reaction products of all the pastes studied are shown in Table 11.

The following deductions that may be drawn from an analysis of the above data for pastes cured for 2 days.

(a) Pastes without admixtures have a somewhat higher $\mathrm{Ca} / \mathrm{Si}$ ratio than those containing $1 \%$ of the $\mathrm{PC}$ superplasticiser.

(b) $\mathrm{The} \mathrm{Al} / \mathrm{Si}$ ratio is similar in the two pastes.

(c) $\mathrm{The} \mathrm{Al} / \mathrm{Ca}$ ratios are essentially the same in the two pastes.

The results obtained after 28 days of hydration show the following.

(a) The $\mathrm{Ca} / \mathrm{Si}$ ratio is only slightly higher in the paste without admixtures, in contrast to the finding after 2 days.

(b) No differences were found between the $\mathrm{Al} / \mathrm{Si}$ ratios for the two pastes. The final values were slightly lower than after 2 days of hydration.

(c) $\mathrm{The} \mathrm{Al} / \mathrm{Ca}$ ratio is not impacted by curing age or the presence of the admixture.

\section{Rheological behaviour}

As cement pastes are plastic fluids, their rheological behaviour can be fitted to Bingham's model:

$$
\tau=\tau_{\mathrm{o}}+\mu \gamma
$$

where $\tau$ is the shear stress; $\mu$ is the plastic viscosity defined to be the internal friction or the resistance of the paste to flow when subject to a velocity gradient (in 


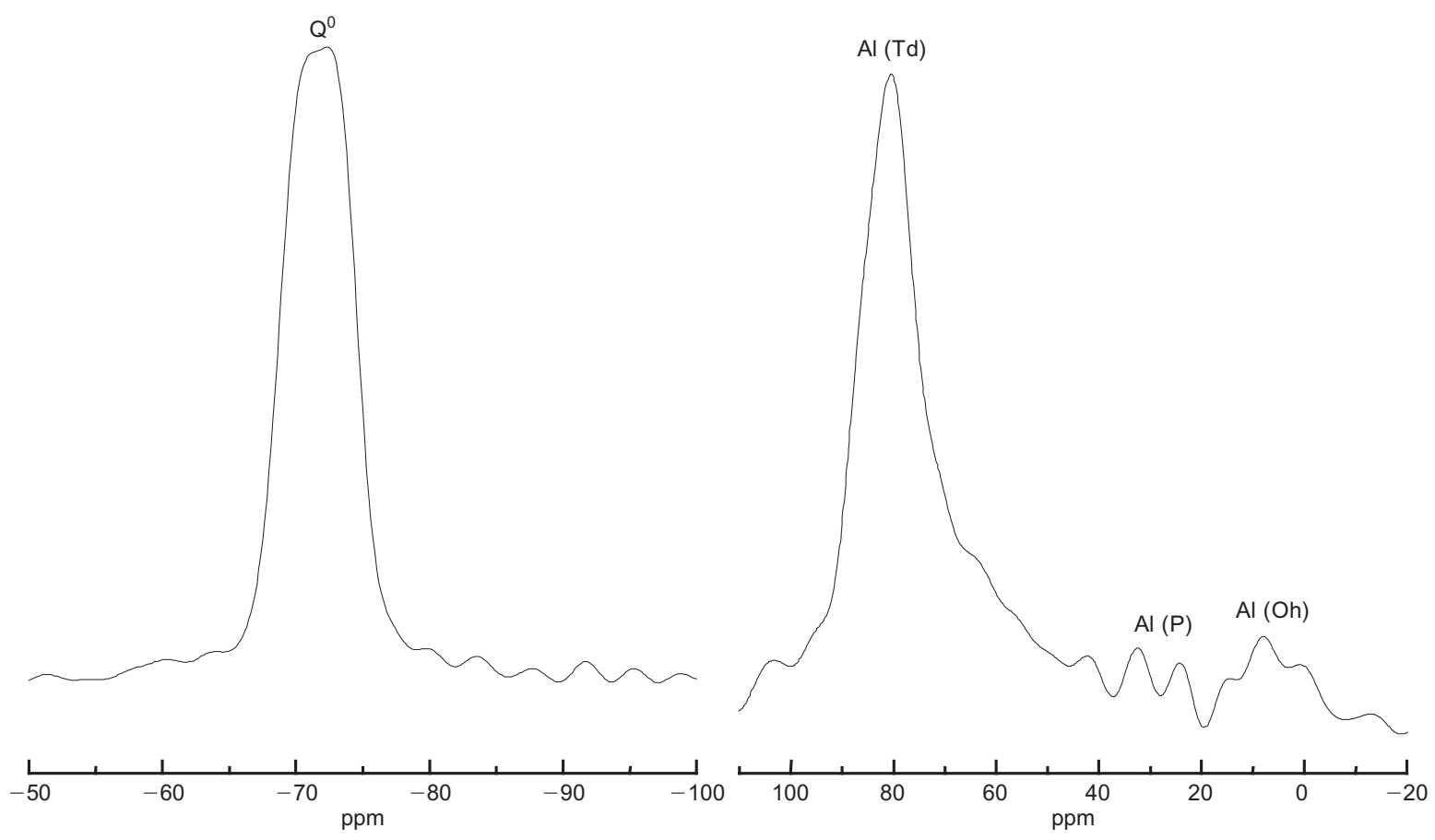

(a)
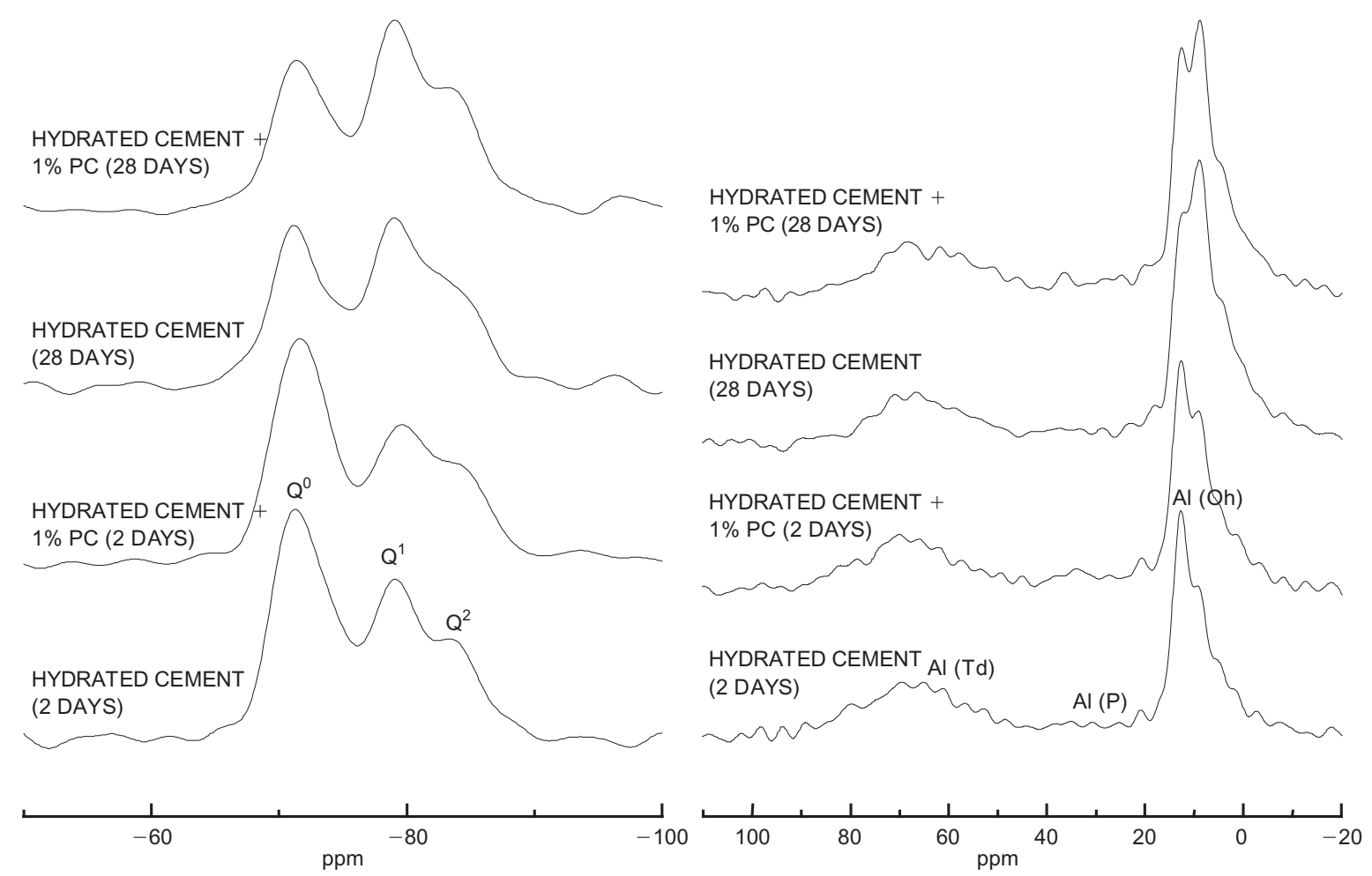

(b)

Fig. 5. (a) FT-Raman spectra of cement pastes with $1 \%$ of PC at 2 and 28 days of curing; (b) ${ }^{29}$ Si and ${ }^{27}$ Al MNR spectra of anhydrous cement and cement pastes at 2 and 28 days of curing

cement pastes, such viscosity is on the order of $1 \mathrm{~Pa} \mathrm{~s}$ ); $\gamma$ is the shear rate and $\tau_{\mathrm{o}}$ is the yield stress.

Plastic viscosity and shear stress can be determined by plotting the decline in shear rate values against stress. As Bingham's equation is linear, viscosity is the slope of the respective line and the $y$-axis value is the yield stress (Fig. 7). Table 12 shows the numerical values found for these parameters.

Plastic viscosity provides an indication of the number and dimensions of the flocs formed during cement 
Table 7. Data obtained by deconvolution of ${ }^{29} \mathrm{Si}$ NMR spectra of cement pastes

\begin{tabular}{|c|c|c|c|c|c|c|}
\hline Pastes & $\mathrm{Q}^{1}$ (Alite, belite, ...) & $\mathrm{Q}^{1}$ (end of Caín) & $\mathrm{Q}^{2}(0 \mathrm{Al})$ & $\mathrm{Q}^{2} / \mathrm{Q}^{1}$ & $\mathrm{CL}$ & $\alpha$ \\
\hline Anhydrous cement & $-72 \cdot 06 \mathrm{ppm}$ & & & - & - & - \\
\hline Without admixture 2 days & $\begin{array}{l}-72 \cdot 00 \mathrm{ppm} \\
W=5 \cdot 30 \\
I=49 \cdot 79 \%\end{array}$ & $\begin{array}{c}-79 \cdot 28 \mathrm{ppm} \\
5 \cdot 20 \\
32 \cdot 70 \%\end{array}$ & $\begin{array}{c}-84 \cdot 70 \mathrm{ppm} \\
5 \cdot 27 \\
17 \cdot 55 \%\end{array}$ & $0 \cdot 54$ & $3 \cdot 07$ & $50 \cdot 25$ \\
\hline Without admixture 28 days & $\begin{array}{l}-71 \cdot 70 \mathrm{ppm} \\
W=5 \cdot 27 \\
I=39 \cdot 26 \%\end{array}$ & $\begin{array}{c}-79 \cdot 30 \mathrm{ppm} \\
5 \cdot 21 \\
38.83 \%\end{array}$ & $\begin{array}{c}-84.61 \mathrm{ppm} \\
5 \cdot 28 \\
21.91 \%\end{array}$ & $0 \cdot 56$ & $3 \cdot 12$ & $60 \cdot 74$ \\
\hline $1 \%$ Admixture 2 days & $\begin{array}{l}-72 \cdot 10 \mathrm{ppm} \\
W=5 \cdot 30 \\
I=50 \cdot 20 \%\end{array}$ & $\begin{array}{c}-79 \cdot 80 \mathrm{ppm} \\
5 \cdot 10 \\
29 \cdot 43 \%\end{array}$ & $\begin{array}{c}-85 \cdot 00 \mathrm{ppm} \\
5 \cdot 10 \\
20 \cdot 37 \%\end{array}$ & 0.69 & $3 \cdot 38$ & $49 \cdot 80$ \\
\hline $1 \%$ Admixture 28 days & $\begin{array}{l}-71.96 \mathrm{ppm} \\
W=5 \cdot 10 \\
I=34 \cdot 50 \%\end{array}$ & $\begin{array}{c}-79.38 \mathrm{ppm} \\
4.99 \\
40.73 \%\end{array}$ & $\begin{array}{c}-84 \cdot 55 \mathrm{ppm} \\
5 \cdot 10 \\
24 \cdot 78 \%\end{array}$ & $0 \cdot 61$ & $3 \cdot 22$ & $65 \cdot 51$ \\
\hline
\end{tabular}

W: width; $I$ : integral; CL: chain length; $\alpha$ : reaction degree

Table 8. Results obtained by ${ }^{27}$ Al NMR of cement pastes

\begin{tabular}{|c|c|c|c|c|c|c|c|c|}
\hline \multirow{2}{*}{$\frac{\text { Pastes }}{\text { Anhydrous cement }}$} & \multicolumn{2}{|c|}{$\mathrm{Al}_{\mathrm{T}}$} & $\mathrm{Al}_{\mathrm{P}}$ & \multicolumn{5}{|c|}{$\mathrm{Al}_{\mathrm{O}}$} \\
\hline & $\begin{array}{c}80.89 \mathrm{ppm} \\
W=14.69 \\
I=71.73 \%\end{array}$ & $\begin{array}{l}62 \cdot 00 \mathrm{ppm} \\
14 \cdot 69 \\
13 \cdot 43 \%\end{array}$ & $\begin{array}{l}34 \cdot 42 \mathrm{ppm} \\
14 \cdot 79 \\
6 \cdot 14 \%\end{array}$ & & & $\begin{array}{l}6 \cdot 42 \mathrm{ppm} \\
14 \cdot 70 \\
8 \cdot 70 \%\end{array}$ & & \\
\hline Without admixture & & $67 \cdot 35 \mathrm{ppm}$ & $31.00 \mathrm{ppm}$ & $12 \cdot 72 \mathrm{ppm}$ & $8.82 \mathrm{ppm}$ & & $4.66 \mathrm{ppm}$ & $1.00 \mathrm{ppm}$ \\
\hline 2 days & & $\begin{aligned} W & =28 \cdot 84 \\
I & =45 \cdot 87 \%\end{aligned}$ & $\begin{array}{l}15 \cdot 78 \\
4 \cdot 73 \%\end{array}$ & $\begin{array}{c}4 \cdot 00 \\
27 \cdot 13 \%\end{array}$ & $\begin{array}{c}4 \cdot 00 \\
13 \cdot 13 \%\end{array}$ & & $\begin{array}{l}4 \cdot 00 \\
5 \cdot 60 \%\end{array}$ & $\begin{array}{l}4 \cdot 00 \\
3 \cdot 54 \%\end{array}$ \\
\hline Without admixture & & $67 \cdot 30 \mathrm{ppm}$ & $35 \cdot 00 \mathrm{ppm}$ & $12 \cdot 50 \mathrm{ppm}$ & $8.80 \mathrm{ppm}$ & & $4 \cdot 30 \mathrm{ppm}$ & $1.00 \mathrm{ppm}$ \\
\hline 28 days & & $\begin{aligned} W & =23 \cdot 00 \\
I & =31.90 \%\end{aligned}$ & $\begin{array}{l}15 \cdot 00 \\
4 \cdot 42 \%\end{array}$ & $\begin{array}{c}4 \cdot 20 \\
20 \cdot 27 \%\end{array}$ & $\begin{array}{c}4 \cdot 20 \\
27 \cdot 55 \%\end{array}$ & & $\begin{array}{c}4 \cdot 20 \\
10 \cdot 20 \%\end{array}$ & $\begin{array}{l}4 \cdot 20 \\
5 \cdot 66 \%\end{array}$ \\
\hline $1 \%$ admixture & & $68.58 \mathrm{ppm}$ & $32 \cdot 83 \mathrm{ppm}$ & $12.73 \mathrm{ppm}$ & $8.79 \mathrm{ppm}$ & & $4.68 \mathrm{ppm}$ & $1.00 \mathrm{ppm}$ \\
\hline 2 days & & $\begin{aligned} W & =24 \cdot 13 \\
I & =40 \cdot 28 \%\end{aligned}$ & $\begin{array}{l}13 \cdot 21 \\
6 \cdot 34 \%\end{array}$ & $\begin{array}{c}4 \cdot 11 \\
26 \cdot 52 \%\end{array}$ & $\begin{array}{c}4 \cdot 11 \\
16 \cdot 78 \%\end{array}$ & & $\begin{array}{l}4 \cdot 11 \\
5 \cdot 71 \%\end{array}$ & $\begin{array}{l}4 \cdot 11 \\
4 \cdot 37 \%\end{array}$ \\
\hline $1 \%$ admixture & & $65 \cdot 01 \mathrm{ppm}$ & $33.00 \mathrm{ppm}$ & $12 \cdot 61 \mathrm{ppm}$ & $8.70 \mathrm{ppm}$ & & $4 \cdot 30 \mathrm{ppm}$ & $1.00 \mathrm{ppm}$ \\
\hline 28 days & & $\begin{aligned} W & =25 \cdot 13 \\
I & =34 \cdot 84 \%\end{aligned}$ & $\begin{array}{l}16 \cdot 39 \\
3 \cdot 74 \%\end{array}$ & $\begin{array}{c}4 \cdot 00 \\
20 \cdot 84 \%\end{array}$ & $\begin{array}{c}4 \cdot 24 \\
27 \cdot 34 \%\end{array}$ & & $\begin{array}{l}4 \cdot 24 \\
8 \cdot 20 \%\end{array}$ & $\begin{array}{l}4 \cdot 24 \\
3 \cdot 74 \%\end{array}$ \\
\hline
\end{tabular}

W: width; $I$ : integral

Table 9. Total porosity and average pore diameter

\begin{tabular}{l|c|c}
\hline \multicolumn{2}{|c}{2 days } \\
\hline $\begin{array}{l}\text { Dosage } \\
\text { admixture: } \%\end{array}$ & $\begin{array}{c}\text { Total porosity: } \\
\%\end{array}$ & $\begin{array}{c}\text { Average pore diameter } \\
\text { (volume): } \mu \mathrm{m}\end{array}$ \\
\hline 0 & $20 \cdot 48$ & $0 \cdot 0280$ \\
$0 \cdot 3$ & $21 \cdot 16$ & $0 \cdot 0251$ \\
$0 \cdot 5$ & $19 \cdot 76$ & $0 \cdot 0241$ \\
$0 \cdot 7$ & $18 \cdot 12$ & $0 \cdot 0238$ \\
1 & $18 \cdot 22$ & $0 \cdot 0228$ \\
\hline & \multicolumn{2}{|c}{28 days } \\
\hline Dosage & Total porosity: & Average pore diameter \\
admixture: $\%$ & $\%$ & (volume): $\mu \mathrm{m}$ \\
\hline 0 & $14 \cdot 43$ & $0 \cdot 0192$ \\
$0 \cdot 3$ & $15 \cdot 80$ & $0 \cdot 0173$ \\
$0 \cdot 5$ & $14 \cdot 12$ & $0 \cdot 0187$ \\
$0 \cdot 7$ & $14 \cdot 25$ & $0 \cdot 0180$ \\
1 & $13 \cdot 92$ & $0 \cdot 0193$ \\
\hline
\end{tabular}

hydration and subsequently dispersed, and shear stress is associated with the binding or cohesive strength of these flocs. ${ }^{27}$ The results in the table show that plastic viscosity decreases as the dosage of admixture increases, thereby drastically reducing yield stress.
Table 10. Distribution of pore size in cement pastes

\begin{tabular}{l|c|c|c|c|c}
\hline \multicolumn{6}{c}{2 days } \\
\hline & 0 & 0.3 & 0.5 & 0.7 & 1 \\
\hline $\begin{array}{l}\text { Air porous } \\
(>10 \mu \mathrm{m})\end{array}$ & 1.76 & 1.84 & 1.49 & 2.79 & 1.35 \\
$\begin{array}{l}\text { Macropores } \\
(10-0.05 \mu \mathrm{m})\end{array}$ & 8.88 & 10.06 & 8.57 & 5.98 & 4.97 \\
$\begin{array}{l}\text { Mesopores } \\
(0.05-0.0025 \mu \mathrm{m})\end{array}$ & 89.36 & 88.1 & 89.94 & 91.23 & 93.68 \\
\hline \multicolumn{5}{|c}{28 days } \\
\hline $\begin{array}{l}\text { Air porous } \\
(>10 \mu \mathrm{m})\end{array}$ & 3.42 & 2.68 & 2.50 & 3.60 & 2.45 \\
$\begin{array}{l}\text { Macropores } \\
(10-0.05 \mu \mathrm{m})\end{array}$ & 5.13 & 3.84 & 4.47 & 5.07 & 3.82 \\
$\begin{array}{l}\text { Mesopores } \\
(0.05-0.0025 \mu \mathrm{m})\end{array}$ & 91.44 & 93.47 & 93.02 & 91.32 & 93.72 \\
\hline
\end{tabular}

\section{Discussion}

The results obtained with respect to the effect of PC admixture on cement hydration show that at very early ages it retards the initial cement hydration. This effect is more acute at higher doses of superplasticiser. This 


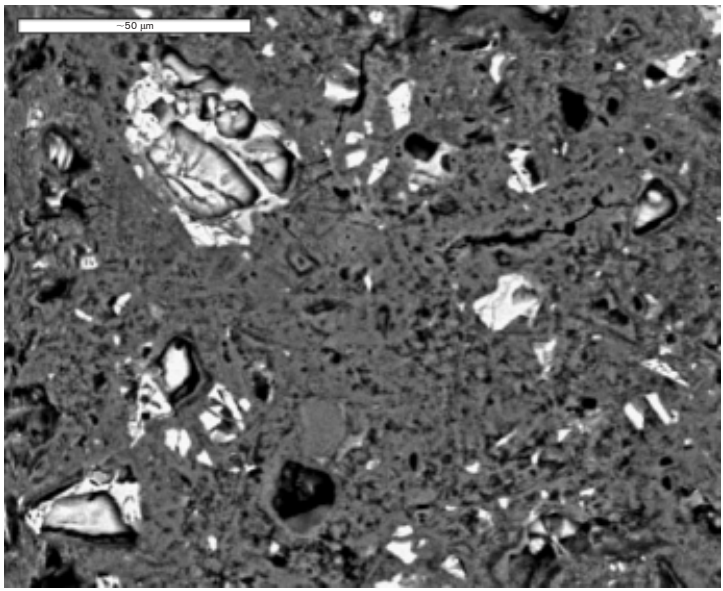

(a) Without PC (2 days)

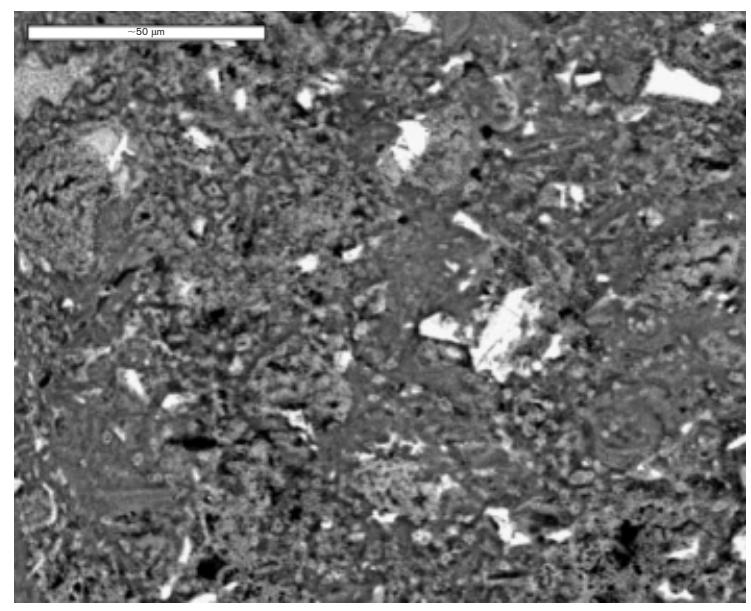

(c) Without PC (28 days)

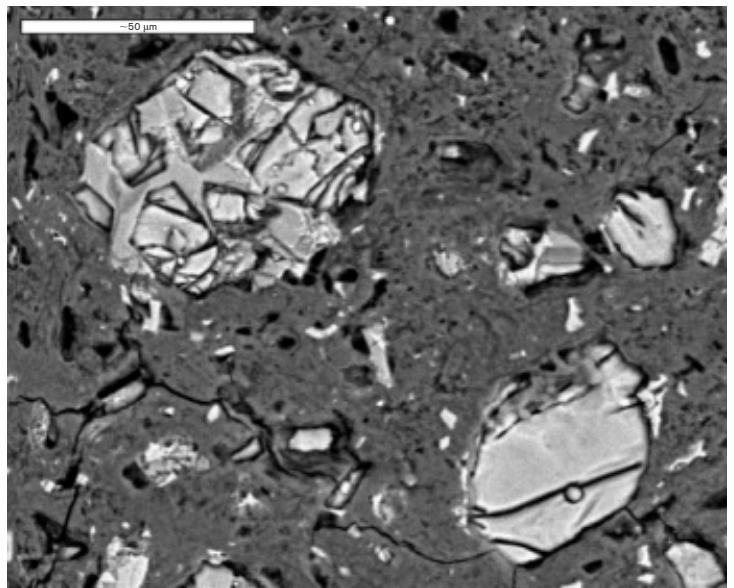

(b) With PC (2 days)

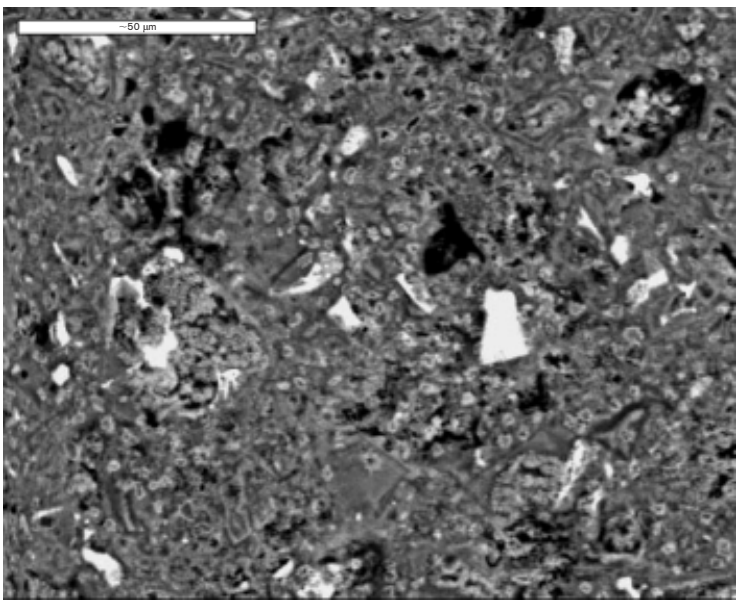

(d) With PC (28 days)

Fig. 6. BSE micrographs of the studied pastes

Table 11. Atomic ratio determined by BSE/EDX

\begin{tabular}{|c|c|c|}
\hline \multicolumn{3}{|c|}{2 days } \\
\hline & Without admixture & $1 \%$ admixture \\
\hline $\begin{array}{l}\text { No of analysis } \\
10\end{array}$ & $\begin{array}{l}\mathrm{Ca} / \mathrm{Si}: 2.29(0.24) \\
\mathrm{Al} / \mathrm{Ca}: 0 \cdot 10(0.02) \\
\mathrm{Al} / \mathrm{Si}: 0.26(0.05)\end{array}$ & $\begin{array}{lll}\mathrm{Ca} / \mathrm{Si}: & 1 \cdot 91 & (0 \cdot 17) \\
\mathrm{Al} / \mathrm{Ca}: & 0 \cdot 14 & (0 \cdot 02) \\
\mathrm{Al} / \mathrm{Si}: & 0 \cdot 26 & (0.02)\end{array}$ \\
\hline \multicolumn{3}{|c|}{28 days } \\
\hline $\begin{array}{l}\text { No of analysis } \\
10\end{array}$ & $\begin{array}{l}\mathrm{Ca} / \mathrm{Si}: 1.90(0.18) \\
\mathrm{Al} / \mathrm{Ca}: 0.13(0.02) \\
\mathrm{Al} / \mathrm{Si}: 0.23(0.03)\end{array}$ & $\begin{array}{lll}\mathrm{Ca} / \mathrm{Si}: & 2.03 & (0.29) \\
\mathrm{Al} / \mathrm{Ca}: & 0 \cdot 13 & (0.02) \\
\mathrm{Al} / \mathrm{Si}: & 0.24 & (0.01)\end{array}$ \\
\hline
\end{tabular}

phenomenon is confirmed by the results obtained in conduction calorimetry, with a retardation of the peak time for the first peak in the heat release rate curves, associated with $\mathrm{C}-\mathrm{S}-\mathrm{H}$ gel and $\mathrm{CH}$ precipitation. This lower initial precipitation of reaction products is further corroborated by the smaller weight loss detected in 2day cured pastes with admixtures, when subjected to temperatures of $110-600^{\circ} \mathrm{C}$. Such weight loss is due to the partial and total dehydration of reaction products. The delay in hydration reactions is expressed as a very substantial lengthening of the initial and final setting times of the pastes that have high dosages of admixture.

SNF and SMF superplasticisers also produce delays in initial cement hydration reactions, a development that is closely related to the adsorption of the compounds to the surface of cement particles or some of the hydration products. ${ }^{11}$ PC admixtures likewise adsorb on the surface of cement particles, with a dispersive capacity that is dependent upon the amount adsorbed. According to Yamada and Hanehara, ${ }^{28}$ such adsorption is affected by two important factors: the specific area of the solid phases and possible competition with other anionic species, such as sulphate ions, in the adsorption process. ${ }^{29}$ Some authors note that this admixture, like sulphonated naphthalenes (SNF), adsorbs more readily to $\mathrm{C}_{3} \mathrm{~A}$ than to calcium silicates. As a result of such adsorption, a change takes place in the ionic composition of the aqueous phase, thereby altering the equilibrium with the compatible solid phases. In short, in its interactions with the reactive species, the 


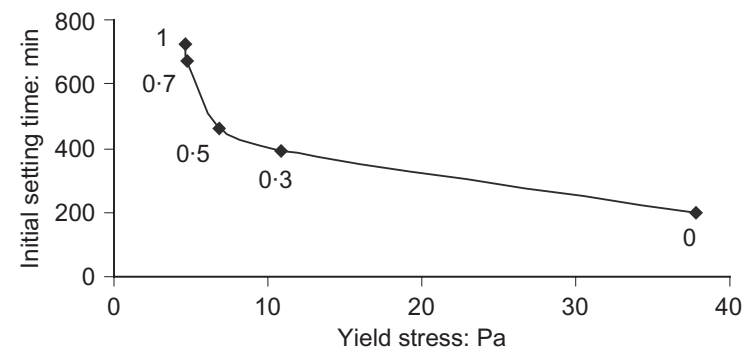

Fig. 7. Relation between rheological parameters and setting times

Table 12. Rheological parameters of the cement pastes studied

\begin{tabular}{l|c|c}
\hline $\begin{array}{l}\text { Dosage admixture: } \\
\%\end{array}$ & $\begin{array}{c}\mu \text { plastic viscosity: } \\
\text { Pa s }\end{array}$ & $\begin{array}{c}\tau_{\mathrm{o}} \text { yield stress: } \\
\text { Pa }\end{array}$ \\
\hline 0 & $0 \cdot 8$ & $37 \cdot 8$ \\
$0 \cdot 3$ & $0 \cdot 7$ & $10 \cdot 9$ \\
$0 \cdot 5$ & $0 \cdot 4$ & $6 \cdot 8$ \\
$0 \cdot 7$ & $0 \cdot 3$ & $4 \cdot 7$ \\
1 & $0 \cdot 3$ & $4 \cdot 6$ \\
\hline
\end{tabular}

organic admixture affects hydrated phase diffusion, nucleation and growth and therefore the hydration process.

Setting is related to the concentration of $\mathrm{Ca}^{2+}$ ions in the liquid phase: retarded setting is attributed to a decrease in the concentration of such $\mathrm{Ca}^{2+}$ ions. Using $\mathrm{X}$-ray photoelectron spectroscopy or electron spectroscopy for chemical analysis (ESCA), Uchikawa et al. ${ }^{5}$ showed that a chelate forms in pastes with $\mathrm{PC}$ admixtures as a result of the interaction between the $\mathrm{Ca}^{2+}$ ions and the admixture molecules. The formation of this chelate would lower the $\mathrm{Ca}^{2+}$ concentration and thereby retard setting and hinder solid phase nucleation. This, in turn, would explain the lengthening of the induction period observed in the heat release rate curves when the dosage of the PC admixture is increased (Fig. 2 and Table 4). Jolicoeur and Simard ${ }^{30}$ found similar results with more conventional superplasticisers. This retardation of $\mathrm{C}-\mathrm{S}-\mathrm{H}$ and $\mathrm{CH}$, as well as in AFt, nucleation and growth, is the reason for the lower weight loss obtained with thermogravimetric analysis (Table 5) in 2-day pastes containing the admixture.

Reactive processes continue over time and, as the calorimetric data show, more intensely in the pastes with admixtures (higher heat release rates and more heat released); for this reason, the amount of product is similar in all pastes after 28 days, with no meaningful differences in weight loss at that age. These results are confirmed by XRD and FT-Raman data. The highly dispersive effect of PC admixture initially decreasing the hydration rate by the mechanism described above, nonetheless subsequently favours ionic diffusion (due to the separation between particles), intensifying the reactive processes and increasing reaction speed. This, in turn, would explain the higher heat release rate and greater amount of total heat released in pastes with admixtures. Furthermore, the NMR data at 28 days confirm an increase of the degree of reaction.

Whereas retardation of the initial hydration reactions can be deduced from the formation of a smaller amount of product in paste with admixtures, the results of the XRD, FT-Raman and FTIR mineralogical analyses show that the same hydration products are formed in all pastes. The electron microscopy findings likewise indicate that there are no morphological alterations of any importance due to the presence of admixtures in the pastes.

Differences of some significance were observed, however, in the porosity data: after 2 days of hydration, as the PC admixture content increased, total porosity declined and the pore structure became more refined, with a rise in the percentage of mesopores and a decline in the macropore content. Roncero et al. ${ }^{31}$ reported similar results, observing a decrease in total porosity and in the distribution of pore size in cement pastes which contained different types of superplasticiser admixtures (a polycarboxylate admixture among them). Their results refer to pastes cured at 7 and 28 days. In our study, however, we observed no variations in porosity or in the size distribution of pores in pastes cured for 28 days.

Another relevant finding in this study is the lower weight loss observed in the thermogravimetric data for pastes with higher doses of PC admixture after 2 days of hydration at temperatures ranging from 600 to $1050^{\circ} \mathrm{C}$ (see Table 5). This temperature range is essentially associated with weight loss due to the decomposition of calcium carbonates present in the samples. FTIR showed no notable decreases in the absorption bands characteristic of $\mathrm{CO}_{3}$ groups $\left(1500-1400 \mathrm{~cm}^{-1}, 840-890 \mathrm{~cm}^{-1}\right.$ and $720-710 \mathrm{~cm}^{-1}$ ). What is observed, on the contrary, is a reduction in total porosity and mean pore diameter, along with an increase in the mesopore content, as mentioned above. Electron microscopy also revealed lower levels of porosity. These results indicate that the PC admixture used in this study induced microstructural modifications in the pastes which reduce porosity and induce a refinement in pore size, the effect of which is that the paste is less liable to carbonation.

The presence of PC admixture in pastes induced few alterations in the structure and composition of the $\mathrm{C}$ $\mathrm{S}-\mathrm{H}$ gel formed in the pastes. According to the data obtained by ${ }^{29} \mathrm{Si}$ NMR spectra and especially at early ages, the $\mathrm{C}-\mathrm{S}-\mathrm{H}$ gel formed with $1 \%$ PC presents a higher percentage of silicate bridge (units $\mathrm{Si} \mathrm{Q}^{2}$ ). Roncero et $a l .^{32}$ did not detect the presence of $\mathrm{Q}^{2}$ units in pastes with different admixtures (including a PC), but in the present study these units were identified. The higher amount of $\mathrm{Q}^{2}$ units at 2 days in pastes with admixture is in concordance with the EDX data (see 
Table 11). In these pastes the $\mathrm{Ca} / \mathrm{Si}$ ratio is slightly lower than those without PC. However, the results obtained at 28 days of reaction by FTIR and SEM/EDX show that the $\mathrm{C}-\mathrm{S}-\mathrm{H}$ gel formed with admixture has a higher $\mathrm{Ca} / \mathrm{Si}$ ratio. These findings are not completely confirmed by NMR results.

The presence of admixtures does not seem to affect the mechanical strength of the paste at either 2 or 28 days of hydration (see results in Table 3). After 2 days, the pastes with superplasticiser have smaller amounts of reaction products $(\mathrm{C}-\mathrm{S}-\mathrm{H}$ gel $)$, their mechanical behaviour appears to be more closely related to the pore structure (decrease in the size of the pores) and, very likely, to a better distribution of the different components. Legrand and Warquin ${ }^{33}$ found that in the presence of superplasticisers, despite a decrease in hydrate formation, strengths were comparable, and explained this development by the better dispersion of cement particles.

The rheological behaviour of the pastes is given in Table 11. These results show the high dispersive effect of PC admixtures on cement particles. Low dosages of PC $(0 \cdot 3)$ lead to a substantial reduction (over $70 \%)$ in the yield stress. This means that the flocs formed are either not interconnected or the respective cohesive forces are much weaker. In this type of admixtures, steric repulsion is the prevalent force in the dispersion of anhydrous and hydrated cement particles. ${ }^{34}$ Such high dispersion affects reactive processes by decreasing the initial reaction speed. Fig. 6 shows the effect of admixture dosage on the relationship between yield stress and initial setting times. Particle dispersion can be seen to be closely related to the retardation of hydration reactions that takes place even at low dosages of admixture.

\section{Conclusions}

The results obtained with respect to the effect of the PC admixture on cement hydration show that at very early ages an initial retardation of cement hydration is produced. This effect is more pronounced at higher doses of superplasticiser. In its interactions with the reactive species, the organic admixture affects hydrated phase diffusion, nucleation and growth and therefore the hydration process.

Mineralogical analyses show that the same hydration products are formed in all pastes (mainly $\mathrm{C}-\mathrm{S}-\mathrm{H}$ gel), the amount of this product is similar after 28 days of hydration. Additionally, the results obtained by different spectroscopy techniques reveal a few alterations in the structure and composition of $\mathrm{C}-\mathrm{S}-\mathrm{H}$ gel originated in the samples. The $\mathrm{C}-\mathrm{S}-\mathrm{H}$ gel formed presents $\mathrm{Q}^{1}$ dimeric, $\mathrm{Q}^{1}$ end of chain and $\mathrm{Q}^{2}$ units. The addition of $1 \%$ PC admixture in the pastes produces a higher percentage of silicate bridge ( $\mathrm{Si} \mathrm{Q}^{2}$ units) mainly at 2 days.
The results presented in this paper indicate that the PC admixtures used in this study induced microstructural modifications in the pastes which in turn reduce porosity and induce a refinement in pore size, the effect of which is that the paste is less liable to carbonation.

However, the presence of admixtures does not affect paste mechanical strength at either 2 or 28 days of hydration.

Finally, from the results from rheological studies it can be concluded that low dosage of PC leads to a substantial reduction (over 70\%) in the yield stress. This means that the flocs formed are either not interconnected or the respective cohesive forces are much weaker.

\section{Acknowledgements}

The authors wish to thank the Ministry of Science and Technology for the funding for project MAT20011490, without which this study would not have been possible. They are likewise grateful to A. Gil, J. L. García, M. Alonso, L. Ureña and J. Llueca for their collaboration in the mechanical, spectroscopy and microscopic tests and Dr I. Sobrados for her comments and contributions in connection with the NMR studies. The authors are also grateful to J. V. Garcia-Ramos for the facility using FT-Raman spectrometry. Dr. S. Martinez-Ramirez also wishes to thank the Spanish Ministry of Science and Technology for the contract awarded to her under the programme to co-finance the hire of scientific personnel in private enterprise and research centres.

\section{References}

1. Hanehara S. and Yamada K. Interaction between cement and chemical admixture from the point of cement hydration, absorption behaviour of admixture, and paste rheology. Cement and Concrete Research, 1999, 29, No. 8, 1159-1165.

2. Kauppi A., Banfill P. F. G., Bowen P., Galmiche L., Houst Y. F., Lafuma F., Mader U., Perche F., Petersen B. G., Rekns K., Schober I., Siebold A. and Swift D. Improved superplasticizers for high performance concrete. Proceedings of the XI International Conference on the Chemistry of Cement, Durban, 2003, pp. 528-536.

3. Edmeades R. M. and Hewlett P. C. Cement admixtures. In: Lea's Chemistry of Cement and Concrete. 4th edn, (H. Arnold (ed)). John Wiley, London, 1998, pp. 837-896.

4. Yamada K., Takahashi T., Henahara S. and Matsuhira M. Effects of the chemical structure on the properties of polycarboxylate-type superplasticizer. Cement and Concrete Research, 2000, 30, No. 2, 197-207.

5. Uchikawa H., Sawaki D. and Hanehara S. Influence of kind and added timing organic admixture on the composition, structure and property of fresh cement paste. Cement and Concrete Research, 1995, 25, No. 2, 353-364.

6. Sugiyama T., Оhta A. and Uоmoto T. The dispersing mechanism and applications of polycarboxylate-based super- 
plasticizers. Proceedings of the XI International Conference on the Chemistry of Cement, Durban, 2003, pp. 560-568.

7. Magarotto R., Torresan I. and Zeminian N. Influence of the molecular weight of polycarboxylate ether superplasticizers on the rheological properties of fresh cement pastes, mortar and concrete. Proceedings of the XI International Conference on the Chemistry of Cement, Durban, 2003, pp. 514-526.

8. Fernández Cánovas M. El papel de los aditivos en los nuevos hormigones. Proceedings of the $V$ Symposium of Asociación Nacional de Fabricantes de Hormigón y Mortero, 2001.

9. Puertas F. and VázQuez T. Early hydration cement. Effect of admixtures and superplasticizers. Materiales de Construcción, 2001, 51, No. 262, 53-61.

10. Prince W., Espagne M. and Aïtcin P. C. Ettringite formation: A crucial step in cement superplasticizer compatibility. Cement and Concrete Research, 2003, 33, No. 5, 635-641.

11. Mollah M. Y. A., Adams W. J., Schennach R. and Cocke D. L. A review of cement-superplasticizer interactions and their models. Advances in Cement Research, 2000, 12, No. 4, $153-161$.

12. Ramachandran S., Malhotra V. M., Jolicoeur C. and Spratos N. Superplasticizers: Properties and Applications in Concrete. CAMET, Ottawa, Canada, 1998.

13. Collepardi M. and Ramachandran V. S. Effect of admixtures. Proceedings of the IX International Conference on the Chemistry of Cement, New Delhi, 1992, Vol. I, pp. 529-568.

14. Moulin E. M. and Broyer V. Effect of sperplasticizer type on the fluidity retention of Portland cement mortars as a function of the $\mathrm{C}_{3} \mathrm{~A}$ level and the nature of added calcium sulfates. Proceedings of the XI International Conference on the Chemistry of Cement, Durban, 2003, pp. 550-558.

15. Ferraris C. F., Obla K. H., Schennach S. and Cocke D. L. The influence of mineral admixtures on the rheology of cement paste and concrete. Cement and Concrete Research, 2001, 31, No. 2, 245-255.

16. Palacios M., Sierra C. and Puertas F. Techniques and methods of characterization of admixtures for the concrete. Materiales de Construcción, 2003, 53, No. 269, 89-105.

17. Schramm G. A Practical Approach to Rheology and Rheometry. Haake Rheometer, Karlsruhe, 1994.

18. Jawed J., Skalny J. and Young J. F. Hydration of Portland Cement. Structure and Performance of Cements, (BARNeS P. (ed.)). Applied Science Publishers, Essex, 1983, pp. 284-285.

19. de la Cruz I., Vázquez T. and Fernández Peña O. Espectroscopía IR de sulfatos en clínkeres y cementos. Materiales de Construcción, 1986, 36, No. 201, 25-42.

20. Bensted J. Studies of ettringite and its derivatives. Cement Technology, 1971, May/June, 73-77.

21. Bensted J. Some applications of infrared and Raman spectroscopy in cement chemistry. Cement Technology, 1974, July/August, 378-382.

22. Puertas F., Fernández-Jiménez A. and Blanco-Varela M.
T. Pore solution in alkali-activated slag cement pastes. Relation to the composition and structure of calcium silicate hydrate. Cement and Concrete Research, 2004, 34, No. 1, 139-148.

23. Kirkpatrick R. J., Yarger J. L., McMillan P. F., Yu P. and ConG X. Raman spectroscopy of $\mathrm{C}-\mathrm{S}-\mathrm{H}$, torbermorite, and jenite. Advanced Cement Based Materials, 1997, 5, 93-99.

24. Dyer C. D., Patrick J. H. and Forsling W. The Raman spectroscopy of cement minerals under $1064 \mathrm{~nm}$ excitation. Spectrochimica Acta, 1993, 49, No. 5/6, 715-722.

25. Kirkpatrick R. J. and Cong X.-D. An introduction to ${ }^{27} \mathrm{Al}$ and ${ }^{29} \mathrm{Si}$ NMR spectroscopy of cements and concretes. In Application of NMR Spectroscopy to Cement Science, (Colombet P. and Grimmer A. (eds)). Gordon \& Breach, Amsterdam, 1994, pp. 55-76.

26. Skibsted J., Henderson E. and Jakobsen H. J. Characterization of calcium aluminate phases in cements by ${ }^{27} \mathrm{Al}$ MAS NMR spectroscopy. Inorganic Chemistry, 1993, 32, No. 6, 1013-1027.

27. Tattersall G. H. and Banfill P. F. G. The Rheology of Fresh Concrete, Pitman, London, 1983.

28. Yamada $\mathrm{K}$. and Hanehara S. Working mechanism of polycarboxylate superplasticizer considering the chemical structure and cement characteristics. Proceedings of the XI International Conference on the Chemistry of Cement, Durban, 2003, 2, pp. 538-548.

29. YAMADA $\mathrm{K}$. and Hanehara S. Interaction mechanism of cement and superplasticizers. The role of polymer adsorption and ionic conditions of aqueous phase. Concrete Science Engineering, 2001, 3, September, 135-145.

30. Jolicoeur C. and Simard M. A. Chemical admixture-cement interactions: Phenomenology and physico-chemical concepts. Cement and Concrete Composite, 1998, 28, 87-101.

31. Roncero J., Gettu R. and Martín M. A. Influencia de los superplastificantes y aditivos reductores de retracción en el comportamiento diferido del hormigón estructural. Proceedings of the V Symposium of Asociación Nacional de Fabricantes de Hormigón y Mortero, 2001.

32. Roncero J., Valls S. and Gettu R. Study of the influence of superplasticizers on the hydration of cement paste using nuclear magnetic resonance and X-ray diffraction techniques. Cement and Concrete Research, 2002, 32, No. 1, 103-108.

33. Legrand C. and Wirquin E. Study of the strength of very young concrete as a function of the amount of hydrates formed-influence of superplasticizer. Materials and Structures, 1994, 27, No. 166, 106-109.

34. Uchikawa H., Hanehara S. and Sawaki D. The role of steric repulsive force in the dispersion of cement particles in fresh paste prepared with organic admixture. Cement and Concrete Research, 1997, 27, No. 1, 37-50.

Discussion contributions on this paper should reach the editor by 1 October 2005 